\title{
A instrução utilitária da publicidade
}

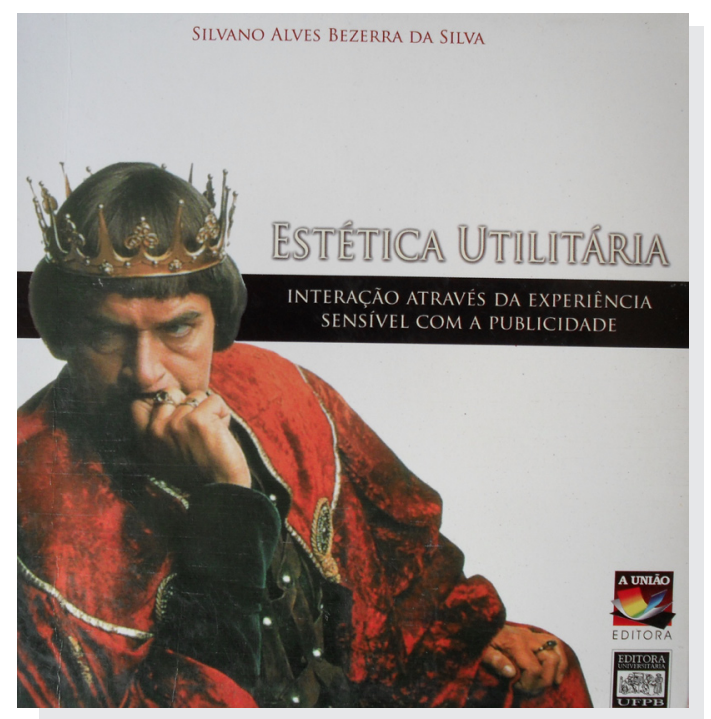

SILVA, Silvano Alves Bezerra da. Estética utilitária: interação através da experiência sensível com a publicidade. João Pessoa: A União Editora/Editora da UFPB, 2010.

\section{Luciana Pletsch Galhardi}

Mestranda do Programa de Pós-Graduação em Comunicação Social da PUCRS/RS/BR. luciana.galhardi@acad.pucrs.br

A publicidade, além de cumprir sua função prática de venda comercial, muitas vezes, utiliza técnicas para produzir um estado de aceitabilidade nos consumidores, ou até mesmo, encantá-los através da estética das peças. O estudo de Silvano Alves Bezerra da Silva concentra suas atenções sobre os processos interacionais que a publicidade trava com gêneros e estilos artísticos, bem como sobre as experiências promovidas por esta arte comercial.

Enquanto a maior parte das produções publicitárias na área da estética possui um caráter predominantemente didático, trazendo fórmulas ou dicas, a proposta do livro é fazer um exercício sensível, no qual se fundamenta numa plataforma diferenciada, e não apenas na apreciação, abordando a estética como utilidade. A obra analisa anúncios de campanhas publicitárias para compreender a consistência desta diferença de base introduzida pela "instrução" utilitária; e as características e qualidade da arte publicitária quando promove interações com os públicos através das experiências estéticas. É pela dimensão do estético que a publicidade interage com as plateias, combinação esta que funciona como um poderoso instrumento de disposições para a compra.

Os processos sensivo-cognitivos desencadeados através da experiência estética publicitária são poderosos liames trabalhados a jeito de modo a constituir vínculos intersubjetivos com coisas e mercadorias, que se revelam não só indispensáveis como centrais na tarefa de persuadir os públicos (Silva, 2010, p. 21).

Dividido em três partes, o livro busca responder as questões: Como se trata de materiais simbólico-sensíveis associados à mercancia, como 
neles se manifestam os vínculos entre arte e comércio? Se a publicidade é, como se sustenta, produção artística dos media, sob que condições e limites se manifesta o instituto de criação? E ainda, como as experiências estéticas com a publicidade são promovedoras de estímulos capazes de persuadir alguém em direção a produtos serviços e marcas?

Por esses motivos entre arte e negócio, sensibilidade e comércio, prazer estético e mercancia é que a obra propõe a experiência estética utilitária levada adiante da publicidade. Segundo o autor, são "as contingências econômicas que fazem pender o fiel da balança artística para a obtenção de resultados estéticos eficazes, depositando o peso no melhor e mais proveitoso potencial útil que a arte possa trazer aos fins da mercancia" (Silva, 2010, p. 58). Portanto, sua perspectiva está determinada por interesses externos a atingir, e, por isso mesmo, vê-se limitadas as esferas simbólicas mais adaptáveis ao objeto prático, utilitário. Trata-se aí, da beleza eficaz.

\section{Como se trata de materiais simbólico-sensíveis} associados à mercancia, como neles se manifestam os vínculos entre arte e comércio? Se a publicidade é, como se sustenta, produção artística dos media, sob que condições e limites se manifesta o instituto de criação? E ainda, como as experiências estéticas com a publicidade são promovedoras de estímulos capazes de persuadir alguém em direção a produtos, serviços e marcas?

A primeira parte do livro aborda o núcleo conceitual, onde fala de fusão e difusibilidade, no qual relata que a publicidade faz uso de vários procedimentos artísticos de vanguarda na qual se verifica uma "complexa malha de soluções de arte", visando provocar interesse, informar, convencer e finalmente, o ato de comprar.

As fusões transcritas pelo autor fazem referência, não da mercadoria em si, em sua existência objetal, e sim, de discursos sobre ela, e também sobre os traços artístico-estéticos da publicidade. Os caminhos da arte e da arte publicitária se cruzam, se misturam, através de fusões complexas.

A difusibilidade está relacionada com a experiência estética, cujo autor escolhe aspectos significativos para extrair suas conclusões: a) a po- tencialidade mobilizadora característica de experiência estética em suas peculiaridades interacionais entre texto e leitor, ou seja, sua capacidade de afetar estados de ânimo e emoções justamente porque faz brotar uma experimentação sensorial, sentimental, intelectual; b) potencialidades que não se esgotam nos convencionais espaços de exercício do artístico e que se abrem para setores marcados por preocupações utilitárias funcionais, como no caso da publicidade.

A segunda parte do livro aborda o núcleo proposicional, no qual se expõe as diferenças da experiência sensível promovida pela publicidade, frente às demais formas artísticas, através da expressão estética utilitária. Por ela, pretende-se indicar o seu funcionamento sensível, destacando sua condição específica na promoção de intensidades estéticas.

Tanto o objeto-matéria, elaborado pelo design, quanto o discurso-do-objeto, forjado pela publicidade, são corpus significantes produzidos ao ritmo da indústria e do comércio, de maneira a fazer do consumível algo personalizado, novo, que se distingue não tanto por sua palpável fisicidade e propriedades constitutivas, mas por sua diferença simbólica (Silva, 2010, p. 63).

Em síntese, segundo o autor, as vendas são, em nossos dias, em grande parte, coordenadas por sensações e emoções.

A funcionalidade simbólica participa diretamente do efeito estético: o objeto enquanto tal, destinado a cumprir funções precisas, conta com o coeficiente estético que, por sua vez, ressalta e destaca a sua utilidade. Esse usufruto das ocupações e fazeres, das relações com as pequenas coisas, como ricas em satisfações sensório-emocionais, corresponde à expansão dos prazeres estéticos.

O denominativo estética utilitária não referencia o trabalho discursivo sobre o uso relativo a produtos, utensílios e serviços, mas, sim, diz respeito à exploração de materiais simbólicos que pretendem sensibilizar os públicos para algo externo ao âmbito de sua própria estrutura discursiva, que é o produto, a mercadoria.

O autor seleciona características do texto publicitário naquilo que é mais capaz de referenciar a sua dinâmica estética, e que o torna diferenciado como fatura simbólica apta a promover experiências sensíveis e cognitivas singulares: a) uma modalidade textual cujos artifícios artís- 
ticos acham-se comprometidos com a realidade imediata; b) textos criativos que não transcendem os limites de compreensão média; c) textos que se movem sobre aspectos do cotidiano e cuja; d) dimensão temporal é no agora; e) brevidade e f) tensões geradas por pretensões estéticas.

A terceira parte do livro aborda o núcleo analítico, no qual têm por objeto de estudo anúncios veiculados em revistas nacionais e internacionais. Os anúncios que integram o corpus da obra foram extraídos das revistas nacionais de grande circulação (Veja, ISTO É, Ana Maria); edição comemorativa de campanha publicitária da Bom Bril; livro resultante de pesquisa acadêmica sobre campanhas da Benetton; anuários de publicidade nacionais e internacionais.

A análise visa verificar no material publicitário o que reserva em termos de experiência estética, os efeitos estimuladores sobre o leitor instituído pelo trabalho enunciativo. Dois níveis de interação são contemplados: uma referente aos domínios da produção (as inter-relações entre textos, faturas culturais, formas, modos saberes artísticos); e outra relativa aos domínios do reconhecimento (as virtuais relações entre leitor-e-texto, visualizáveis através das previsões de leitura ensejadas pelos trabalhos de enunciação). Tanto em um como em outro, objetiva-se apreender certas singularidades processadas quer em relação aos atributos da forma discursiva, quer às cobranças, às solicitações que a forma faz ao leitor-espectador.

$\mathrm{O}$ autor traça considerações em torno das $\mathrm{ca}$ tegorias estéticas para depois delinear os percursos de análise. Essas categorias são combinatórias organizadas, um sistema de exigências para que certa combinação artística ou extra-artística - como no caso da publicidade - alcance um determinado gênero, como o dramático, o cômico, o grotesco, o agradável, etc. De modo aproximativo, as categorias permitem verificar vínculos entre forma e estrutura, práticas e hábitos mentais, organizando assim a relação entre o que é interno e o que é externo a um objeto estético, de forma que esse objeto encontre eco na ambiência afetivo-intelectual do receptor. São elas: um ethos (uma atmosfera afetiva especializada); um sistema de forças estruturadas; um tipo especializado de valor; e o trânsito estético.

Silvano traz em sua pesquisa um quadro de Étienne Souriau, de categorias estéticas criado em 1933. Trata-se de um diagrama com 24 ramos. A relevância desse diagrama se justifica por três motivos: os valores nele agrupados se originam de dois paradigmas estéticos, o ideal clássico e o ideal romântico; o diagrama é ampliado, abrigando categorias menores, integrando assim, uma força poderosa por trás da constituição de tensão entre sujeitos; e, por último, em razão da influência acentuada que seus estudos sobre as categorias estéticas exerceram nessa área da pesquisa.

Souriau (1993) incluiu os valores do estilo clássico - o cômico, o sublime, o belo, o trágico, o bonito e o grotesco - e os provenientes do sistema romântico de valores - o enfático, o patético, o dramático, o irônico o fantástico, o poético. A estes, Souriau (1993) intercalou mais 12 categorias menores, obtendo um quadro de estações complementares - o nobre, o grandioso, o espiritual, o pitoresco, o gracioso, o lírico, o heroico, o pírrico, o melodramático, o caricatural, o satírico, o elegíaco.

Conforme o autor, toda experiência estética é um acontecimento extraordinário, que se destaca da vida rotineira e que vincula intensamente um sujeito a determinado objeto dotado de singularidade ou percebido como tal.

Após passar pela experiência estética, o mais comum é o indivíduo lembrar-se dela como sabor nostálgico, porque a intensidade vivida não se perde, se acrescenta à experiência como episódio quase insuperável de abandono, se não prazeroso, intenso (Silva, 2010, p. 104).

Trazendo essa definição sobre a experiência estética, Silvano acredita que o criativo, na publicidade, usa de mecanismos verbais e icônicos para forjar liames que permitem comunicar sentimentos, estados de espírito, a fim de gerar excitação e algum prazer fruitivo em interagentes, em direção a produtos e serviços.

Em face da singularidade do fenômeno estético utilitário empreendido pela publicidade, foram definidos ângulos para as análises de forma que permitam associar as categorias estéticas a contributos da teoria de Mikhail Bakhtin com sua Estética da criação verbal (2000), que traz indicativos consistentes de que a construção discursiva é produção linguística e extralinguística, elaboração concreta, projeção de leitura e de efeitos sensíveis.

Com isso, pretendeu-se demonstrar que o movimento incorporar-modificar-se afastando - que tem por função caracterizar certo deslocamento 
realizado através de fusões com gêneros, estilos, modalidades e saberes pertencentes às artes do popular; e uma nova conformação resultante da passagem para uma outra região da produção simbólica - pôde explorar os específicos estímulos sensíveis que põe em ação. E para que, no segmento final do estudo, fosse possível extrair as mais destacáveis consequências desse fenômeno mediático.

Essa análise estética do material publicitário sugeriu fixar parâmetros que permitissem, de um lado, focalizar os níveis interacionais, e, de outro, atentar para a natureza específica do fenômeno estético.

As análises dos anúncios avançaram parcialmente para as provocações de sentidos, por outro lado pretenderam dar conta da direção que os estímulos sensíveis tomam como potencializadores de estados emocionais, aptos a gerar disposições "favoráveis" no leitor acerca dos bens ou serviços, e suas possíveis reações sensivo-cognitivas - condição sine qua non de seu processo de incorporar-modificar-se afastando, que marca a transubstanciação processada pela autopoiésis publicitária.
Então o estímulo sensível foi canalizado para este fim; o que operou a conversão da categoria estética, transformando-a, segundo a perspectiva utilitária, num mecanismo se não condutor, pelo menos estimulador, de venda - daí o caráter tangenciado do enfoque analítico.

Concluindo, os efeitos dos processos estéticocomerciais da publicidade produziram alterações significativas na sensibilidade coletiva coetânea, abrindo perspectivas de estímulo à experiência sensível, ao mesmo tempo em que se fez portadora de urgentes interesses mercadológicos.

Os preceitos bakhtinianos ajudaram a perceber os múltiplos cruzamentos que a arte publicitária realiza com diferentes áreas da produção artísticas, negociando com elas as formas mais eficazes de se instituir comunicação e instigar a compra. Tais diálogos revelaram o paradoxo que acompanha o intrincado fazer publicitário: de um lado, a publicidade opera com o que de mais gratuito e gratificante nos fornece a linguagem: o jogo, a imaginação, a poesia; de outro, a diferenciação instituída pelo jogo da arte precisa ser contido, para dar espaço à mercadoria. 